\title{
Childhood Testicular Non-Seminomatous Germ Cell Tumor
}

National Cancer Institute

\section{Source}

National Cancer Institute. Childhood Testicular Non-Seminomatous Germ Cell Tumor. NCl Thesaurus. Code C123843.

A non-seminomatous germ cell tumor that arises in the testis and occurs in children. 